\title{
CHEMICAL COMPOSITION AND DECOMPOSITION RATE OF PLANTS USED AS GREEN MANURE
}

\author{
Gabriela Tavares Arantes Silva룬 Laudiceio Viana Matos²; Pedro de Oliveira Nóbrega'; \\ Eduardo Francia Carneiro Campello ${ }^{3}$; Alexander Silva de Resende ${ }^{3 *}$ \\ ${ }^{1}$ UFRRJ - Programa de Pós-Graduação em Ciências Ambientais e Florestais, BR 465, km 7 - 23890-000 - \\ Seropédica, RJ - Brasil. \\ ${ }^{2}$ UFV - Programa de Pós-Graduação em Nutrição Vegetal, Av. Peter Henry Rolfs, s/n - 36570-000 - Viçosa, MG - Brasil \\ ${ }^{3}$ Embrapa Agrobiologia - BR 465, km 7 - 23890-000 - Seropédica, RJ - Brasil. \\ *Corresponding author <alex@cnpab.embrapa.br>
}

\begin{abstract}
Productive systems in which green manure is the source of nutrients must develop more efficient ways to improve soil nutrient dynamics. A well-synchronized balance must be established between specific crop demands and supply of nutrients from decomposition. However, scientific data and information to help improve green manure management in Brazil is still insufficient. For that reason, a number of arboreal species was first chemically characterized and then subjected to decomposition analysis in order to establish a correlation between some parameters. Species were grouped together based on the similarity of chemical composition and decomposition rate. The lignin:N and (lignin+polyphenol): $\mathrm{N}$ ratios were found to have the greatest correlation coefficient with the dry matter decomposition rate and nitrogen release.
\end{abstract}

Key words: nutrient recycling, half life time, agroforest system

\section{COMPOSIÇÃO QUÍMICA E VELOCIDADE DE DECOMPOSIÇÃO DE PLANTAS VISANDO AADUBAÇÃO VERDE}

\begin{abstract}
RESUMO: Sistemas produtivos que utilizam a adubação verde prezam por uma dinâmica mais eficiente de nutrientes no solo. Nesse sentido, é importante buscar a sincronia entre a demanda nutricional da cultura e a disponibilidade de nutrientes provenientes da decomposição. Esse estudo objetivou estabelecer uma correlação entre a composição química e a velocidade de decomposição de espécies em um sistema agroflorestal. Para tanto, realizou-se a caracterização química de espécies arbóreas, seguida de estudos de decomposição e busca de correlação entre os parâmetros analisados. De posse dos resultados, foi possível agrupar espécies com composição química e taxas de decomposição semelhantes. As relações lignina:N e (lignina+polifenol): N apresentaram os maiores coeficientes de correlação com a velocidade de decomposição de massa seca e liberação de nitrogênio.

Palavras-chave: ciclagem de nutrientes, tempo de meia vida, sistema agroflorestal
\end{abstract}

\section{INTRODUCTION}

In agroforest systems (AFS) the main input of nutrients is achieved through biomass decomposition, by which elements that are essential for plant development and are associated to plant tissues not readily available to crops of commercial interest are released. How fast these residues return to the soil is basically a function of the quality of the organic source, the weather conditions and the presence of decomposing organisms in the system (Swift et al., 1979). In order to develop more efficient systems to improve soil nutrient dynamics, a well-synchronized balance must be established between specific crop demands and supply of nutrients from decomposition.

The objective of the present study was to evaluate the fertilizing potential of ten species, determining their chemical composition, decomposition rate, nitrogen release and the correlation between the decomposition rate and chemical composition.

\section{MATERIAL AND METHODS}

The initial step of this study consisted of selecting 24 species, which would then be further analyzed for polyphenol and nitrogen contents, and the C:N ratio. Next, and based on the obtained results, the selected species were grouped according to a $\mathrm{C}: \mathrm{N}$ ratio range. After that, some species were selected from each group to study their decomposition processes. Table 1 lists the evaluated species and their phenological stage during field sampling.

Field sampling was conducted in a silvopastoral system, over an Alfisol, in March 2004 when all plants 
Table 1 - Evaluated species.

\begin{tabular}{|c|c|c|}
\hline Scientific Name & Common Name & Phenological Stage \\
\hline Acacia angustissima ${ }^{1}$ & Acácia & Vegetative growth \\
\hline Acacia auriculiformis ${ }^{1}$ & Acácia auriculada & Flowering \\
\hline Acacia mangium ${ }^{1}$ & Acacia Australiana & Flowering \\
\hline Albizia guachapelel & Albizia & Vegetative growth \\
\hline Albizia lebbek ${ }^{1}$ & Coração de Negro & Vegetative growth \\
\hline Albizia saman & Saman & Vegetative growth \\
\hline Brachiaria decumbens ${ }^{2}$ & Braquiária & Vegetative growth \\
\hline Centrolobium tomentosus ${ }^{I}$ & Araribá & Flowering \\
\hline Enterolobium contorsiliquum ${ }^{I}$ & Orelha de negro & Vegetative growth \\
\hline Erythrina poerpigiana ${ }^{I}$ & Mulungu do alto & Vegetative growth \\
\hline Gliricidia sepium ${ }^{l}$ & Gliricidia & Vegetative growth \\
\hline Inga semialata ${ }^{1}$ & Inga margoso & Flowering and fruiting \\
\hline Leucaena leucocephala & Leucena & Vegetative growth \\
\hline Macherium hirtum ${ }^{1}$ & Jacarandá bico de pato & Vegetative growth \\
\hline Melliah azederach ${ }^{3}$ & Cinamomo & Fruiting \\
\hline Mimosa artemisiana ${ }^{1}$ & Jurema branca & Flowering \\
\hline Mimosa caesalpiniifolia ${ }^{I}$ & Sabiá & Flowering \\
\hline Mimosa tenuiflora ${ }^{1}$ & Jurema preta & Flowering \\
\hline Panicum maximum ${ }^{2}$ & Capim colonião & Vegetative growth \\
\hline Peltophorum dubium ${ }^{I}$ & Canafístula & Vegetative growth \\
\hline Schizolobium parahyba & Guapuruvu & Vegetative growth \\
\hline Senna siamea ${ }^{I}$ & Senna & Flowering and Fruiting \\
\hline Syzygium cumini ${ }^{4}$ & Jamelão & Fruiting \\
\hline
\end{tabular}

Note: ${ }^{1}$ - Leguminosae Family; ${ }^{2}$ - Poaceae Family; ${ }^{3}$ - Meliaceae Family; ${ }^{4}$ - Myrtaceae Family.

were about four years old. The study area is located in Seropédica, RJ, Brazil (22 $46^{\prime}$ ' S and $43^{\circ} 41^{\prime}$ W) at an altitude of $33 \mathrm{~m}$. According to Köppen's classification method, the climate of the region is AW, i.e. tropical wet and dry or savanna climate, with a wet summer and a dry winter. Average annual temperature and precipitation are $24.6^{\circ} \mathrm{C}$ and $1,200 \mathrm{~mm}$, respectively.

During sampling of leaf material, special care was taken to collect only the intermediate leaves of the branches, in an attempt to avoid young leaves and those in an advanced stage of maturity, because during senescence some mobile nutrients are translocated within plant tissues (Raven, 2001). The material was first air-dried to constant weight in a greenhouse, after which the sample material was ground and sent to the laboratory for analysis. Before grinding, subsamples were oven-dried at $65^{\circ} \mathrm{C}$ to determine moisture content, which was later used to correct the data of chemical analysis.

Nitrogen content was determined by the semimicro Kjeldhal method (Bremner \& Mulvaney, 1982), while polyphenol levels were assessed using the Folin-
Denis method (Anderson \& Ingram, 1993). The C:N ratio was obtained by dividing the nitrogen level by an average value for the concentration of carbon, $450 \mathrm{~g}$ $\mathrm{kg}^{-1}$, as calculated by Silva (2006). The results are expressed as the arithmetic mean of four replicates, which were subsequently statistically compared using the Skott-Knott test at the 5\% of significance level. Species were grouped together based on the C:N ratio range. Representative species were selected from each group to study decomposition dynamics. The C:N ratio was chosen because it is a parameter relatively easy to measure, in addition to being extensively documented in the literature. For these two reasons, the C:N ratio is an indicator of the choice to evaluate and study the decomposition rate.

In November 2004, leaf samples of the ten previously selected species were collected using the same standard sampling methods and at the same sampling locations as those described above for the previous stage of the study and with three replicates per species. The evaluated species and their respective phenological stage at the time of sampling are in Table 2. 
Table 2 - Phenological stage of the evaluated species.

\begin{tabular}{lll}
\hline Scientific Name & \multicolumn{1}{c}{ Common Name } & Phenological Stage \\
\hline Acacia auriculiformis & Acácia auriculada & Vegetative growth \\
Acacia holosericea & Holosericea & Fruiting \\
Albizia guachapele & Albizia & Vegetative growth \\
Abizia saman & Saman & Late flowering \\
Brachiaria decumbens & Braquiária & Young and senescent leaves \\
Erythrina poeppigiana & Mulungu do alto & Young leaves \\
Gliricidia sepium & Gliricidia & Young leaves \\
Inga semialata & Inga margoso & Vegetative growth \\
Mimosa caesalpiniifolia & Sabiá & Young and senescent leaves \\
Syzygium cumini & Jamelão & Flowering \\
\hline
\end{tabular}

After the samples had been collected, subsamples were prepared for chemical analysis. The leaves were oven-dried at $65^{\circ} \mathrm{C}$ to constant weight, ground and prepared for laboratory analysis. Nitrogen concentration was determined by the semi-micro method of Kjeldhal (Bremner \& Mulvaney, 1982). Total polyphenol content was determined by the colorimetric procedure using the Folin-Denis reagent, described by Anderson \& Ingram (1993). Lignin was measured by the method of Van Soest (1963) described by Silva (1990), an analysis that also yielded the cellulose content. The carbon level was obtained by total combustion in a LECO CHN 600 Elemental Analyser.

Moisture content was measured by comparative weighing, before and after oven drying of fresh leaf samples. In addition to the dry weight, the following parameters were estimated: C:N, lignin:N, polyphenol: $\mathrm{N}$, cellulose: $\mathrm{N}$ and (lignin +polyphenol): $\mathrm{N}$ ratios. The Skott-Knott test at the 5\% level was employed to separate the means each time when the $\mathrm{F}$ test was significant.

The dynamics of the decomposition processes and rates involving the species here focussed were studied in an agroforest system characterized by a high diversity of species and based on plant succession. This system was initiated in January 2002 in an area located in Seropédica, RJ. During the study period, mean temperature and precipitation were $26.5^{\circ} \mathrm{C}$ and $578.6 \mathrm{~mm}$ (Figure 1), respectively. The experiment started in November 2004 and finished in March 2005, during the rainy season

To evaluate decomposition, $50 \mathrm{~g}$ of fresh leaves of each species were placed in $5 \mathrm{~mm}$ mesh litter bags in a way to allow colonization by microorganisms and invertebrates. The bags were randomly distributed over the study area and left in direct contact with the soil surface.

Decomposition was monitored by harvesting and analyzing the residues at regular time intervals: 5 ,

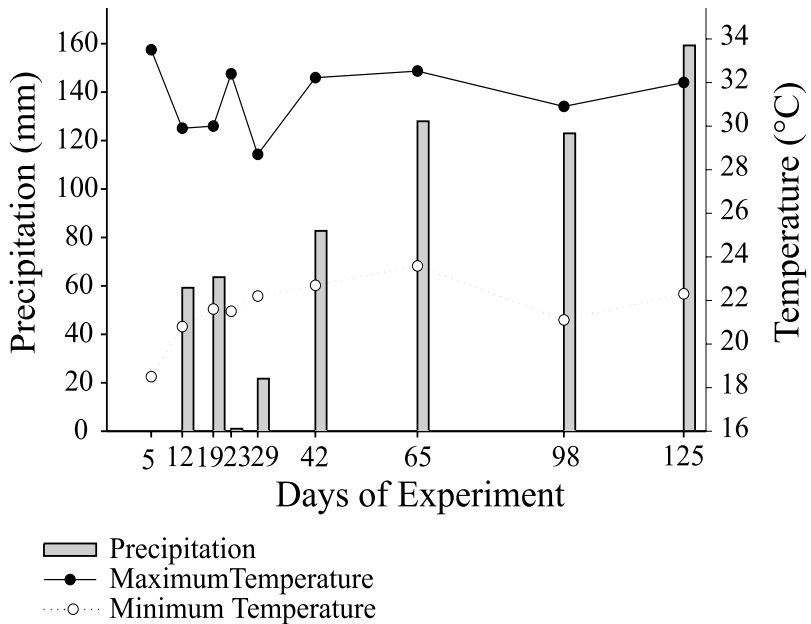

Figure 1 - Maximum and minimum temperatures $\left({ }^{\circ} \mathrm{C}\right)$ and precipitation $(\mathrm{mm})$ during the experimental period, in Seropédica, RJ.

12, 19, 23, 29, 42, 65, 98 and 125 days after beginning of the experiment. The sampling dates were chosen in function of the weather conditions and previous sampling times. Triplicate samples of each species were taken at each sampling time, amounting to a total of 270 samples over the entire experimental period. To characterize the material in an early stage of decomposition, subsamples of the material intended to be taken to the field were oven-dried at $65^{\circ} \mathrm{C}$ to determine initial dry matter. This evaluation was carried out with six replicates. Samples collected on the field were always manually screened for dirt to avoid soil contamination. Samples were always oven-dried $65^{\circ} \mathrm{C}$ for the determination of mass loss and nitrogen content using the semi-micro Kjeldhal method (Bremner Mulvaney, 1982).

The decomposition of the plant material was monitored following the simple exponential decay model developed by Rezende et al. (1999) based on field and laboratory evidence of decomposition rates: 
$\mathrm{k}=\ln \left(\mathrm{X} / \mathrm{X}_{\mathrm{o}}\right) / \mathrm{t}$

where: $\mathrm{X}=$ quantity of dry matter or remaining nitrogen after a period of time $t$; $X_{0}=$ quantity of initial dry matter or nitrogen; $\mathrm{k}=$ decomposition constant; $\mathrm{t}$ =time in days.

The half-life is a parameter used to facilitate the interpretation of plant residue decomposition data, which measures the period of time $(\mathrm{t})$ required by $50 \%$ of the material to be decomposed. From eq (1) it is possible to calculate the half-life as shown bellow:

$\mathrm{t}_{1 / 2}=\ln (2) / \mathrm{k}$

The correlation coefficients (r) were obtained using the computer program Sigmaplot V.6.0. This coefficient establishes a relation between the initial chemical composition of the plants and the decomposition rate. The species Brachiaria decumbens and Syzygium cumini were excluded from this part of the study because they exhibited a very different behaviour from that of the other species studied and also because they were the only non- leguminous species.

\section{RESULTS AND DISCUSSION}

The chemical analyses of the leaves of the species was classified in groups according to their mean C:N ratio values (Table 3). The selected species from each group for further evaluation of their decomposition dynamics in the next stage of this study are highlighted in bold.

A. guachapele, A. saman, E. poeppigiana, A. lebeck, L. leucocephala and A. angustissima were found to contain the highest levels of nitrogen in their leaves, with levels greater than $350 \mathrm{~g} \mathrm{~kg}^{-1}$. High levels of nitrogen are essential in green manure (Costa et al., 2004; Amabile et al., 2000). However, the chemical composition alone does not determine or characterize the fertilizing potential of a species. For this purpose, decomposition parameters should be taken into account

Table 3 - Polyphenol and nitrogen levels, and C:N ratio of leaves of 24 species (Seropédica, RJ, Brazil).

\begin{tabular}{|c|c|c|c|}
\hline Species & Nitrogen & Polyphenol & $\mathrm{C}: \mathrm{N}$ \\
\hline \multicolumn{4}{|c|}{ - } \\
\hline Brachiaria decumbens & $5.80 \mathrm{e}$ & $19.90 \mathrm{~h}$ & 77 a \\
\hline Panicum maximum & $7.31 \mathrm{e}$ & $18.86 \mathrm{~h}$ & 63 a \\
\hline Syzygium cumini & $13.24 \mathrm{~d}$ & $124.97 \mathrm{c}$ & $34 \mathrm{~b}$ \\
\hline Acacia auriculiformis & $22.4 \mathrm{c}$ & $121.89 \mathrm{c}$ & $20 \mathrm{c}$ \\
\hline Acacia holosericea & $23.04 \mathrm{c}$ & $109.13 \mathrm{~d}$ & $19 \mathrm{c}$ \\
\hline Mimosa caesalpiniifolia & $24.78 \mathrm{c}$ & $115.57 \mathrm{c}$ & $18 \mathrm{c}$ \\
\hline Mimosa tenuiflora & $24.65 \mathrm{c}$ & $127.10 \mathrm{c}$ & $18 \mathrm{c}$ \\
\hline Peltophorum dubium & $21.53 \mathrm{c}$ & $208.04 \mathrm{a}$ & $20 \mathrm{c}$ \\
\hline Acacia mangium & $29.14 b$ & $120.03 \mathrm{c}$ & $15 \mathrm{~d}$ \\
\hline Centrolobium tomentosum & $28.45 \mathrm{~b}$ & $82.19 \mathrm{e}$ & $15 \mathrm{~d}$ \\
\hline Gliricidia sepium & $29.32 \mathrm{~b}$ & $57.67 \mathrm{f}$ & $15 \mathrm{~d}$ \\
\hline Inga semialata & $26.06 \mathrm{c}$ & $131.90 \mathrm{c}$ & $17 \mathrm{~d}$ \\
\hline Machaerium isadelphum & $28.15 \mathrm{~b}$ & $156.67 \mathrm{~b}$ & $16 \mathrm{~d}$ \\
\hline Melia azedarach & $26.64 \mathrm{c}$ & $59.69 \mathrm{f}$ & $16 \mathrm{~d}$ \\
\hline Mimosa artemisiana & $28.39 \mathrm{~b}$ & $160.74 \mathrm{~b}$ & $15 \mathrm{~d}$ \\
\hline Schizolobium parahyba & $31.36 \mathrm{~b}$ & $78.08 \mathrm{e}$ & $14 \mathrm{~d}$ \\
\hline Senna siamea & $29.04 \mathrm{~b}$ & $86.79 \mathrm{~d}$ & $15 \mathrm{~d}$ \\
\hline Acacia angustissima & $41.43 \mathrm{a}$ & $158.02 \mathrm{~b}$ & $10 \mathrm{e}$ \\
\hline Albizia guachapele & $35.67 \mathrm{a}$ & $84.46 \mathrm{e}$ & $12 \mathrm{e}$ \\
\hline Albizia lebbeck & 39.56 a & $54.72 \mathrm{f}$ & $11 \mathrm{e}$ \\
\hline Albizia saman & $36.80 \mathrm{a}$ & $39.44 \mathrm{~g}$ & $12 \mathrm{e}$ \\
\hline Enterolobium contortisiliquum & $32.02 \mathrm{~b}$ & $62.45 \mathrm{f}$ & $14 \mathrm{e}$ \\
\hline Erythrina poeppigiana & $38.64 \mathrm{a}$ & $67.81 \mathrm{f}$ & $11 \mathrm{e}$ \\
\hline Leucaena leucocephala & 39.84 a & $157.02 \mathrm{~b}$ & $11 \mathrm{e}$ \\
\hline
\end{tabular}

Mean values followed by same letter are not different (Scott Knott test $P \leq 0.05$ ). Average of four replicates. An estimated carbon concentration of $45 \%$ was taken into account for all species evaluated. 
to enable the determination of the amount of nutrients contained within plant tissues and the time after which these will be released and become available to crops o economic interest.

The chemical analyses on leaf samples of the species selected for the decomposition study (Table 4) was performed with moisture contents ranging from $500 \mathrm{~g} \mathrm{~kg}^{-1}$ to $800 \mathrm{~g} \mathrm{~kg}^{-1}$ for E. poeppigiana. The low value of $I$. semialata as compared to the other species seems to be a distinctive characteristic of this genus. Gonçalo et al. (2000), studied eight Inga species and found average moisture levels of around $520 \mathrm{~g} \mathrm{~kg}^{-1}$.

A comparison between the results of this stage of the study (Table 4) with those of the first stage (Table 3) clearly shows variations in the concentrations of the evaluated components, thereby indicating that the chemical composition of the plants may be influenced by both the time of year and the phenological phase. An example of this is the nitrogen concentration in A. saman, B. decumbens, E. poeppigiana, $G$. sepium and $M$. caesalpiniifolia, which increased on average $36 \%$ from the first to the second sampling time. This increase in nitrogen content is probably associated with the phenological stage of the plant at sampling time. During the second sampling, E. poeppigiana and G. sepium bore young leaves (Table $3)$. Nitrogen is a mobile nutrient in plant tissues and with senescence it will be translocated to young leaves, which will exhibit considerably higher concentrations. (Taiz \& Zeiger, 2004).

During the second sampling period, Brachiaria decumbens and M. caesalpiniifolia had both young and senescent leaves (Table 3 ) and it was difficult to distinguish the leaves in the intermediate stage of leaf development. Therefore, it is possible that a proportionally greater amount of young leaves was included in the sampled material as compared to intermediate leaves. A. saman was in the late flowering stage at the time of sampling. Since this species characteristically loses its older leaves during flowering (Lorenzi et al., 2003), it is possible to conclude that the leaves collected were young and consequently contained high levels of nitrogen.

The levels of polyphenol decreased on average $42 \%$ from the first (Table 3 ) to the second (Table 4) samplings, with exception of $A$. saman and $B$. decumbens. For A. auriculiformis, I. semialata and $M$ caesalpiniifolia, the higher polyphenol content of the first sampling seems to be associated to the presence of flowers (Table 2) which act as a defense mechanism to protect the reproductive structure of the plant against the attack of herbivorous predators.

The ratio between carbon and nitrogen compounds (Table 5) indicates that the following species presented ratios that did not statistically differ one from the other: A. guachapele and A. saman; E. poeppigiana and $G$. sepium. It should be emphasized that in both cases the coupled species differed only in terms of the polyphenol: $\mathrm{N}$ ratio. A. auriculiformis and A. holosericea also differed from each other only in respect of their species-specific polyphenol:N ratio. However, the difference is only of the order of one level of the Scott Knott test.

The previous remarks open the perspective to create groups of species with similar fertilizing potential, which allows the recommendation of a specific group of species for areas characterized by a particular combination of climate, soil and season conditions.

Table 4 - Chemical characterization of the species (Seropédica, RJ, Brazil).

\begin{tabular}{lcccccc}
\hline Species & Humidity & Carbon & Nitrogen & Cellulose & Polyphenol & Lignin \\
\hline Acacia auriculiformis & $618.31 \mathrm{~d}$ & $479.93 \mathrm{a}$ & $24.07 \mathrm{e}$ & $210.35 \mathrm{c}$ & $77.91 \mathrm{a}$ & $110.69 \mathrm{c}$ \\
Acacia holosericea & $565.05 \mathrm{e}$ & $482.04 \mathrm{a}$ & $20.89 \mathrm{f}$ & $186.31 \mathrm{~d}$ & $77.32 \mathrm{a}$ & $109.71 \mathrm{c}$ \\
Albizia guachapele & $606.43 \mathrm{~d}$ & $442.40 \mathrm{c}$ & $35.66 \mathrm{c}$ & $157.69 \mathrm{e}$ & $41.12 \mathrm{c}$ & $99.35 \mathrm{c}$ \\
Albizia saman & $682.1 \mathrm{c}$ & $459.68 \mathrm{c}$ & $42.64 \mathrm{a}$ & $231.05 \mathrm{~b}$ & $41.24 \mathrm{c}$ & $89.97 \mathrm{c}$ \\
Brachiaria decumbens & $697.70 \mathrm{c}$ & $385.10 \mathrm{e}$ & $11.19 \mathrm{~g}$ & $242.63 \mathrm{~b}$ & $25.82 \mathrm{e}$ & $56.32 \mathrm{~d}$ \\
Erythrina poeppigiana & $792.73 \mathrm{a}$ & $425.94 \mathrm{~d}$ & $43.80 \mathrm{a}$ & $140.46 \mathrm{f}$ & $30.61 \mathrm{~d}$ & $78.51 \mathrm{~d}$ \\
Gliricidia sepium & $769.53 \mathrm{~b}$ & $426.87 \mathrm{~d}$ & $38.50 \mathrm{~b}$ & $125.15 \mathrm{f}$ & $31.94 \mathrm{~d}$ & $74.47 \mathrm{~d}$ \\
Inga semialata & $497.28 \mathrm{f}$ & $462.53 \mathrm{~b}$ & $23.63 \mathrm{e}$ & $288.18 \mathrm{a}$ & $72.74 \mathrm{~b}$ & $237.36 \mathrm{a}$ \\
Mimosa caesalpiniifolia & $609.07 \mathrm{~d}$ & $461.81 \mathrm{~b}$ & $31.50 \mathrm{~d}$ & $118.69 \mathrm{f}$ & $72.96 \mathrm{~b}$ & $116.05 \mathrm{c}$ \\
Syzygium cumini & $584.40 \mathrm{e}$ & $460.60 \mathrm{~b}$ & $13.57 \mathrm{~g}$ & $183.97 \mathrm{~d}$ & $74.73 \mathrm{~b}$ & $164.34 \mathrm{~b}$ \\
\hline Coefficient of Variation $(\%)$ & 13.90 & 13.60 & 39.55 & 28.69 & 39.16 & 45.32 \\
\hline
\end{tabular}

Mean values followed by same letter do not differ (Skott Knott test $P \leq 0.05$ ). Means of three replicates. 
In terms of green manure management, consolidation of these groups could be extremely useful and important provided that they express the rate at which each species will release nutrients to the soil. In an attempt to provide information capable of contributing to the achievement of this purpose, Table 6 depicts the decomposition parameters evaluated for the ten selected species.

Table 6 enables the distinction of the groups mentioned above. The species A. guachapele, A. saman, E. poeppigiana and G. sepium exhibit a halflife ranging from 19 to 44 days for dry matter decomposition and from 15 to 33 days for nitrogen release (Table 6). A degree of variation of this magnitude is acceptable if the goal is to estimate an "approximate and indicative" value and not a scientifically exact figure. These species represent a group characterized by rapid decomposition and nitrogen content higher than $35.0 \mathrm{~g} \mathrm{~kg}^{-1}$ (Table 4).
A. holosericea and A. auriculiformis exhibit similar velocities of decomposition, but considerably lower than the decomposition rates of the species mentioned above. Their half-life is 100 and 122 days for dry matter decomposition and 128 and 197 days for nitrogen release (Table 6). These species would be part of the group formed by species of slow decomposition and intermediate nitrogen concentration, i.e. 20.9 $\mathrm{g} \mathrm{kg}^{-1}$ for $A$. holosericea and $24.1 \mathrm{~g} \mathrm{~kg}^{-1}$ for $A$. auriculiformis (Table 4).

The species $B$. decumbens and $S$. cumini were found to have a similar half-life for nitrogen release, 77 and 78 days, respectively. These species however also exhibited the lowest nitrogen content of all evaluated species (Table 4), reason for which they are less indicated for use as fertilizers. I. semialata exhibited the slowest decomposition rate, with a half-life of 225 days for nitrogen release and 269 days for dry matter decomposition. As the decomposition process of this

Table 5 - Chemical Characterization of the species (Seropédica, RJ, Brazil).

\begin{tabular}{lccccc}
\hline Species & C:N & Cellulose:N & Polyphenol:N & Lignin:N & (Lignin+Polyphenol):N \\
\hline Acacia auriculiformis & $19.91 \mathrm{~b}$ & $8.75 \mathrm{c}$ & $3.23 \mathrm{c}$ & $4.59 \mathrm{c}$ & $7.83 \mathrm{c}$ \\
Acacia holosericea & $23.06 \mathrm{~b}$ & $8.92 \mathrm{c}$ & $3.70 \mathrm{~b}$ & $5.25 \mathrm{c}$ & $8.95 \mathrm{c}$ \\
Albizia guachapele & $12.39 \mathrm{c}$ & $4.42 \mathrm{~d}$ & $1.15 \mathrm{e}$ & $2.78 \mathrm{~d}$ & $3.94 \mathrm{e}$ \\
Albizia saman & $10.79 \mathrm{c}$ & $5.43 \mathrm{~d}$ & $0.97 \mathrm{e}$ & $2.11 \mathrm{~d}$ & $3.08 \mathrm{e}$ \\
Brachiaria decumbens & $34.38 \mathrm{a}$ & $22.36 \mathrm{a}$ & $2.30 \mathrm{~d}$ & $5.03 \mathrm{c}$ & $7.33 \mathrm{c}$ \\
Erythrina poeppigiana & $9.72 \mathrm{c}$ & $3.21 \mathrm{~d}$ & $0.70 \mathrm{f}$ & $1.79 \mathrm{~d}$ & $2.49 \mathrm{e}$ \\
Gliricidia sepium & $11.09 \mathrm{c}$ & $3.26 \mathrm{~d}$ & $0.83 \mathrm{f}$ & $1.93 \mathrm{~d}$ & $2.76 \mathrm{e}$ \\
Inga semialata & $19.60 \mathrm{~b}$ & $12.21 \mathrm{~b}$ & $3.08 \mathrm{c}$ & $10.06 \mathrm{~b}$ & $13.14 \mathrm{~b}$ \\
Mimosa caesalpiniifolia & $14.66 \mathrm{c}$ & $3.78 \mathrm{~d}$ & $2.32 \mathrm{~d}$ & $3.68 \mathrm{c}$ & $6.00 \mathrm{~d}$ \\
Syzygium cumini & $33.87 \mathrm{a}$ & $13.59 \mathrm{~b}$ & $5.49 \mathrm{a}$ & $12.08 \mathrm{a}$ & $17.58 \mathrm{a}$ \\
\hline Coefficient of Variation $(\%)$ & 50.69 & 70.59 & 62.74 & 69.35 & 65.34
\end{tabular}

Mean values followed by same letter do not differ from each other (Scott Knott test $P \leq 0.05$ ). Mean of three replicates.

Table 6 - Decomposition rate $(\mathrm{k})$, half-life $\left(\mathrm{t}_{1 / 2}\right)$ in days and determination coefficient $\left(\mathrm{r}^{2}\right)$ of dry matter decomposition and nitrogen release of leaves (Seropédica, RJ, Brazil).

\begin{tabular}{|c|c|c|c|c|c|c|}
\hline \multirow{2}{*}{ Species } & \multicolumn{3}{|c|}{ Dry Matter } & \multicolumn{3}{|c|}{ Nitrogen } \\
\hline & $\mathrm{k}$ & $\mathrm{t}_{1 / 2}$ & $\mathrm{r}^{2}$ & $\mathrm{k}$ & $\mathrm{t}_{1 / 2}$ & $\mathrm{r}^{2}$ \\
\hline Acacia auriculiformis & 0.006 & 122 & $0.97 * *$ & 0.005 & 128 & $0.97 * *$ \\
\hline Acacia holosericea & 0.007 & 100 & $0.99 * *$ & 0.004 & 197 & $0.90 * *$ \\
\hline Albizia guachapele & 0.018 & 38 & $0.98 * *$ & 0.023 & 30 & $0.98 * *$ \\
\hline Abizia saman & 0.016 & 44 & $0.97 * *$ & 0.022 & 33 & $0.99 * *$ \\
\hline Brachiaria decumbens & 0.012 & 58 & $0.98 * *$ & 0.009 & 77 & $0.89 * *$ \\
\hline Erythrina poeppigiana & 0.036 & 19 & $0.98 * *$ & 0.045 & 15 & $0.98 * *$ \\
\hline Gliricidia sepium & 0.033 & 21 & $0.97 * *$ & 0.046 & 15 & $0.95 * *$ \\
\hline Inga semialata & 0.003 & 269 & $0.82 * *$ & 0.003 & 225 & $0.80 * *$ \\
\hline Mimosa caesalpiniifolia & 0.013 & 52 & $0.95 * *$ & 0.014 & 52 & $0.94 * *$ \\
\hline Syzygium cumini & 0.009 & 76 & $0.94 * *$ & 0.009 & 76 & $0.80 * *$ \\
\hline
\end{tabular}

Values followed by ** indicate $1 \%$ of significance, according to $\mathrm{F}$ test. 
species takes place at a very slow pace, it should be used as soil cover instead of as green manure. Another important aspect to be mentioned is the large difference in terms of decomposition rate of this specie as compared to that of the other species of this study. This difference may be related to its high levels of cellulose and lignin, which were the highest among all (Table 4). The influence of lignin on the decomposition rate is widely discussed in the literature (Melillo et al., 1982; Palm \& Sanchez, 1991; Aerts, 1997; Hobbie, 2000). According to Mafongoya et al. (1998), this molecule interacts with the cell wall, providing mechanical protection to cellulose against degradation, thereby retarding decomposition.

I. semialata did not exhibit the expected behaviour predicted by the mathematical model of exponential decay. This model assumes that decomposition occurs faster in the first stages of the process and slows down with time. According to Palm \& Sanchez (1991), this variation in the velocity of the decomposition process is associated with the compounds that are degraded in each phase. The initial or labile phase is characterized by the release of predominantly soluble compounds. Next, in the slower phase that follows, more complex bonds are degraded. However, the loss of material in I. semialata took place at a constant rate throughout the entire study period. There are two hypotheses to explain this. The first is that the period over which the experiment was conducted was not long enough to distinguish the two phases. The other hypothesis is that this specie may not undergo a clearly distinguishable labile phase and that its decomposition process consists of only the (second) slower phase.

The species with high contents of polyphenol and lignin, ranging from 72.9 to $77.9 \mathrm{~g} \mathrm{~kg}^{-1}$ and from 109.7 to $237.3 \mathrm{~g} \mathrm{~kg}^{-1}$ respectively, were also the species with the highest half-life, varying from 52 to 225 days (Tables 5 and 6). Brachiaria decumbens exhibited relatively high half-life values of 58 days for dry matter and 76 days for nitrogen release, in spite of having the lowest levels of lignin, polyphenol and carbon of all other. This may be due to three factors: (1) low nitrogen content leading to high $\mathrm{C}: \mathrm{N}$, lignin: $\mathrm{N}$, polyphenol: $\mathrm{N}$, cellulose: $\mathrm{N}$ and (lignin + poliphenol): $\mathrm{N}$ ratios; (2) its lignin is monocotyledonous lignin which forms more resistant compounds than dicotyledous lignin (Raven et al., 2001); (3) high cellulose content.

The species with a half-life longer than 55 days were those with the highest C:N, cellulose: $\mathrm{N}$, lignin: $\mathrm{N}$ and (lignin + polyphenol): $\mathrm{N}$ ratios, representing a positive correlation between these parameters. Table 7 was elaborated as an attempt to attribute values to the correlation between chemical composition and decomposition velocity.
Table 7 - Correlation coefficient (r) associating chemical composition to the half-life $\left(\mathrm{t}_{1 / 2}\right)$ of dry matter decomposition (DM) and nitrogen release $(\mathrm{N})$ of leguminous species.

\begin{tabular}{lcc}
\hline \multirow{2}{*}{ Parameters } & \multicolumn{2}{c}{$\mathrm{t}_{\mathrm{1} / 2}$} \\
\cline { 2 - 3 } Nitrogen & $\mathrm{DM}$ & $\mathrm{N}$ \\
\hline Humidity & $-0.722^{*}$ & $-0.895^{* *}$ \\
Cellulose & $0.788^{*}$ & $-0.825^{*}$ \\
Carbon & $0.414^{\mathrm{ns}}$ & $0.734^{*}$ \\
\hline Polyphenol & $0.656^{\mathrm{ns}}$ & $0.723^{*}$ \\
\hline Lignin & $0.955^{* *}$ & $0.803^{*}$ \\
Cellulose:N & $0.940^{* *}$ & $0.966^{*}$ \\
\hline C:N & $0.698^{\mathrm{ns}}$ & $0.916^{* *}$ \\
Polyphenol:N & $0.700^{\mathrm{ns}}$ & $0.897 * *$ \\
\hline Lignin:N & $0.982^{* *}$ & $0.925 * *$ \\
(Lignin+Polyphenol):N & $0.948^{* *}$ & $0.970^{* *}$ \\
\hline
\end{tabular}

Values followed by ns = no significant; *= significant when $P<0.05$; ** significant when $P<0.01$.

The strong correlation between cellulose:N, lignin: $\mathrm{N}$ and (lignin + polyphenol): $\mathrm{N}$ ratios and half-life is in accordance with those of other authors (Torres et al., 2005; Mafongoya et al., 1998) indicating that these ratios constitute adequate and accurate indicators of the decomposition rate "in situ" of plant residues. Palm \& Sanchez (1991), Melillo et al. (1982), Hobbie (2000) have been concentrating their research efforts on developing an index that would enable the estimation of the decomposition rate. The climate is known as the most important parameter for this prediction (Aerts, 1997). Although it is impossible to control this parameter, the choice of the species to be used as green manure can be made based on the need for faster or slower nutrient release in addition to the adaptability of the species to local climate and soil conditions.

\section{ACKNOWLEDGEMENT}

To Embrapa Agrobiologia, CNPq and Faperj for financial support. In addition, to Adriana dos Santos, Telmo Félix and Fernando Cunha for their help in field sampling and chemical analysis.

\section{REFERENCES}

AERTS, R. Climate, leaf litter chemistry and leaf litter decomposition in terrestrial ecosystems: a triangular relationship. Oikos, v.79, p.439-449, 1997.

AMABILE, R.F.; FANCELLI, A.L.; CARVALHO, A.M. Comportamento de espécies de adubos verdes em diferentes épocas de semeadura e espaçamento na região dos cerrados. Brasília, Pesquisa Agropecuária Brasileira, v.35, p.47-54, 2000. 
ANDERSON, J.D.; INGRAM, J.S.I. Tropical soil biology and fertility: A hand book of methods. 2.ed. Wallingford: CAB International, 1993. 171p.

BREMNER, J.M.; MULVANEY, C.S. Nitrogen total. In: PAGE, A.L. Methods of soil analysis. Part 2. 2.ed. Madison: SSSA, 1982. p.595-624.

COSTA, G.S.; FRANCO, A.A.; DAMANESCENO R.N.; FARIA, S.M. Aporte de nutrientes pela serrapilheira em uma área degradada revegetada com leguminosas arbóreas. Revista Brasileira de Ciência do Solo, v.28, p.919-927, 2004.

GONÇALO, E.N.; IRMÃO, L.C.; PENEIREIRO, F.M.; BRILHANTE, N.A.; SÓRIA, Z.C.; MOREIRA, A.A.S.e. Decomposição foliar de oito espécies de leguminosas arbóreas go gênero Inga no sudeste do Acre. In: REUNIÃO BRASILEIRA DE MANEJO E CONSERVAÇÃO DO SOLO E DA ÁGUA, 12., Ilhéus, 2000. Anais. Ilhéus, 2000. 1 CD Rom.

HOBBIE, S.E. Interactions between litter lignin and soil nitrogen avaiability during leaf litter decomposition in a Hawaiian Montane Forest. Ecosystems, v.3, p.484-494, 2000.

LORENZI, H.; SOUZA, H.M. de; TORRES, M.A.V.; BACHER, L.B. Árvores exóticas no Brasil: madeireiras, ornamentais e aromáticas. 1.ed. São Paulo: Instituto Plantarum, 2003. 368p.

MAFONGOYA, P.L.; GILLER, K.E.; PALM, C.A. Decomposition and nitrogen release patterns of tree prunnings and litter. Agroforestry Systems, v.38, p.77-97, 1998.

MELILLO, J.M.; ABER, J.D.; MURATORE, J.F. Nitrogen and lignin control of hardwood leaf litter decomposition dynamics. Ecology, v.63, p.621-626, 1982.

PALM, C.A.; SANCHEZ, P.A. Nitrogen release from the leaves of some tropical legumes as affected by their lignin and polyphenolic contents. Soil Biology and Biochemistry, v.23, p.83-88, 1991.

RAVEN, P.H.; EVERT, R.F.; EICHHORN, S.E. Biologia vegetal. 6.ed. Rio de Janeiro: Guanabara Koogan, 2001. 906p.
REZENDE, C. de P.; CANTARUTTI, R.B.; BRAGA, J.M.; GOMIDE, J.A.; PEREIRA, J.M.; FERREIRA, E.; TARRÉ, R.; MACEDO, R.; ALVES, B.J.R.; URQUIAGA, S.; CADISCH, G.; GILLER, K.E.; BODDEY, R.M. Litter deposition and disappearence in Brachiaria pastures in the Atlantic Forest region of the south of Bahia, Brazil. Nutrients Cycling in Agroecosystems, v.54, p.99-112, 1999.

SILVA, D.J. Análise de alimentos (Métodos químicos e biológicos). Viçosa: Imprensa UFV, 1990. 165p.

SILVA, G.T.A.; MATOS, L.V.; NOBREGA, P.O.; CAMPELLO, E.F.C.; RESENDE, A.S. Correlação entre a composição química inicial e a velocidade de decomposição e liberação de nitrogênio de folhas de dez espécies em um sistema agroflorestal. In: CONGRESSO BRASILEIRO DE SISTEMAS AGROFlORESTAIS, 11., Campos dos Goytacazes, 2006. Anais. Campos dos Goytacazes: Universidade Estadual do Norte Fluminense Darcy Ribeiro, 2006. 1 CD-ROM.

SWIFT, M.J.; HEAL, O.W.; ANDERSON, J.M. Decomposition in terrestrial ecosystems. Berkley: University of California Press, 1979. (Studies in Ecology, 5).

TAIZ, L.; ZEIGER, E. Fisiologia vegetal. 3.ed. Porto Alegre: Artmed, 2004. 719p.

TORRES, P.A.; ABRIL, A.B.; BUCHER, E.H. Microbial succession in litter decomposition in the semi-arid Chaco woodland. Soil Biology \& Biochemistry, v.37, p.49-54, 2005.

VAN SOEST, P.J. Use of detergents in the analysis of fibrous feeds II. A rapid method of the determination of fiber and lignin. Journal of the AOAC, v.46, p.829-835, 1963.

Received May 23, 2007

Accepted November 02, 2007 